Boston University School of Law

Scholarly Commons at Boston University School of Law

Faculty Scholarship

1998

Protecting Patients from Discrimination: The Americans with

Disabilities Act and HIV Infection

George J. Annas

Follow this and additional works at: https://scholarship.law.bu.edu/faculty_scholarship

Part of the Health Law and Policy Commons 
Legal Issues in Medicine

\section{Protecting Patients FROM DISCRIMINATION - The Americans with Disabilities Act AND HIV INFECTION}

\author{
George J. AnNAS, J.D., M.P.H.
}

$\mathrm{T}$ HE Americans with Disabilities Act (ADA) was passed in 1990 to expand the reach of the Rehabilitation Act of 1973 and make discrimination on the basis of disability unlawful. ${ }^{1}$ The wheelchair symbol has become a universal sign of disability, but there are, of course, many types of disability that have been the basis of discrimination over the years, including blindness, deafness, epilepsy, cancer, heart disease, and mental retardation. AIDS is a disability under the ADA, and most commentators have assumed that infection with the human immunodeficiency virus (HIV) also qualifies as a disability under this act. It was not, however, until the summer of 1998 that the first discrimination case involving HIV infection or AIDS to reach the U.S. Supreme Court, Bragdon v. Abbott, gave the Court the opportunity to interpret the ADA as it applies to HIV infection and to rule that Congress intended HIV infection to be included as a disability under the law. ${ }^{2}$

\section{THE DENTIST AND HIS PATIENT}

Sidney Abbott has been HIV-positive since 1986 but does not yet have AIDS. In 1994, she went to the office of Randon Bragdon, a dentist in Bangor, Maine, for an appointment. In a pre-examination questionnaire, she noted that she was HIV-positive. After examining Abbott's teeth, Bragdon determined that she had a cavity that needed filling. He informed Abbott that he had a policy against filling cavities in HIV-infected patients in his office but that he would fill the cavity in a hospital if Abbott agreed to pay the additional cost of using the hospital. Abbott declined the offer and brought suit against the dentist under the ADA, alleging discrimination on the basis of her disability.

The ADA states, "No individual shall be discriminated against on the basis of disability in the full and equal enjoyment of the goods, services, facili-

From the Health Law Department, Boston University School of Public Health, Boston.

(C) 1998, Massachusetts Medical Society. ties, privileges, advantages, or accommodations of any place of public accommodation by any person who ... operates a place of public accommodation." The term "public accommodation" is defined as including "the professional office of a health care provider." The prohibition against discrimination contains a qualification that permits discrimination when the person seeking services "poses a direct threat to the health or safety of others."

On the basis of written pleadings and affidavits, the trial court granted the plaintiff summary judgment in her favor, finding that her HIV infection satisfied the ADA's definition of disability and that there was no genuine issue of material fact as to whether her infection posed "a direct threat to the health or safety of others" during a dental procedure. The court relied on an affidavit from an officer of the Centers for Disease Control and Prevention (CDC), stating that dental treatment is safe for dentists as long as they follow universal precautions against blood-borne pathogens. ${ }^{3}$ The Court of Appeals affirmed the decision, but on the safety issue, it relied on the 1993 CDC dentistry guidelines and the policy of the American Dental Association on HIV infection. ${ }^{4}$ These guidelines not only require the routine use of barrier protection, such as gloves and masks, but also require that all dental instruments that penetrate tissue or bone be sterilized by heat. When the case came before the U.S. Supreme Court, the Court certified only two questions for its review: Is HIV infection a disability under the ADA, and should the courts defer to the professional judgment of an individual health care provider who believes a patient's HIV infection poses a direct threat?

\section{HIV AND THE ADA}

Justice Anthony Kennedy wrote the Court's opinion, in which four other justices concurred. The opinion begins with the ADA's definition of disability, which is "(A) a physical or mental impairment [in a person] that substantially limits one or more of the major life activities of such individual; (B) a record of such an impairment; or (C) being regarded as having such an impairment." The Court first considered whether HIV infection itself is a physical impairment. The Court had little problem finding that it is, primarily on the basis of medical literature describing when the infection begins and its "predictable and, as of today, unalterable course." In the Court's words, in the initial stage of HIV infection, "the assault on the immune system is immediate. . . . There is no latency period," although it may be 7 to 11 years before the CD4+ count drops below 200 cells per cubic millimeter of blood. ${ }^{2}$ The Court concluded, "In light of the immediacy with which the virus begins to damage the infected person's white blood cells and the severity of the disease, we hold it is an impairment from the moment of infec- 
tion [and must be regarded] . . . as a physiological disorder with a constant and detrimental effect on the infected person's hemic and lymphatic systems from the moment of infection." 2

To qualify as a disability according to the ADA's definition, the impairment must not only be physical or mental but must also limit a major life activity. Abbott argued that since HIV infection could reasonably cause a person to decide not to have a child, it affected reproduction, which she also argued is a major life activity. The Court agreed and noted specifically, "Reproduction and the sexual dynamics surrounding it are central to the life process itself." ${ }^{2}$ The Court further noted that HIV infection could substantially limit one's ability to reproduce in two independent ways: by putting one's sexual partner "at significant risk of becoming infected," and by risking infection of one's offspring through perinatal transmission of HIV. ${ }^{2}$

The Court was not impressed with the arguments that the risk of transmission to the child can be reduced to 8 percent and that reproduction with HIV infection was still possible, although it is more risky than without HIV infection. In the Court's words, "the disability definition does not turn on personal choice. When significant limitations result from the impairment, the definition is met even if the difficulties are not insurmountable." 2 The Court found that Abbott's statement that her HIV infection "controlled her decision not to have a child" was "unchallenged." Therefore, the Court concluded that her HIV infection was a physical impairment that substantially limited a major life activity. The Court thus found it unnecessary to decide whether HIV infection alone is a disability under the ADA in all cases.

\section{RISKS TO HEALTH CARE PROVIDERS}

The only question remaining was whether the dentist could use his "professional judgment" of risk to refuse to provide treatment in his office. The Court decided that a personal judgment, even one made in good faith, was insufficient under the ADA. In the Court's words, "As a health care professional, petitioner had the duty to assess the risk of infection based on the objective, scientific information available to him and others in his profession." 2 Using the standard of objective scientific evidence, the Supreme Court concluded that the Court of Appeals had properly refused to give any weight to the dentist's offer to treat the patient in a hospital, because the dentist had provided no "objective, medical evidence showing that treating [the patient] in a hospital would be safer."

A related question was what role statements by public health authorities and professional organizations should have in setting the standards for the profession. The Court concluded that the statements of such organizations are "of special weight and authority" but that they are "not conclusive," and a health care professional who disagrees with them may refute them "by citing a credible scientific basis for deviating from the accepted norm."

The Court also addressed the reliance of the Court of Appeals on the CDC dentistry guidelines and the standards of the American Dental Association. The CDC guidelines recommend the use of universal precautions, which "should reduce the risk of disease transmission in the dental environment." Unlike the Court of Appeals, the Supreme Court thought that judges could not make a determination of risk on the basis of the guidelines alone, because the guidelines suggest "the best way to combat the risk of HIV transmission. They do not assess the level of risk." 2 Nor was the American Dental Association's conclusion that patients with HIV infection "may be safely treated in private dental offices when appropriate infection control procedures are $\mathrm{em}$ ployed" found a sufficient basis on which to judge risks. ${ }^{2}$ The Court found it commendable that the association encouraged its members to provide care for HIV-infected patients but concluded that the question, under the ADA, was "one of statistical likelihood, not professional responsibility." Thus, despite serious doubt that the dentist will be able to produce any scientific evidence to support his fears, the Court remanded the case to the Court of Appeals to determine whether its conclusion on the risk to the dentist would change if it considered more than just the CDC and American Dental Association guidelines. Oral arguments are unlikely to take place before the end of the year.

\section{THE DISSENT}

Chief Justice William Rehnquist wrote a dissenting opinion for himself and three other justices. He was willing to assume that HIV infection is a physical impairment (a point the dentist did not challenge). But he disagreed that reproduction is a major life activity under the ADA "in the same sense that 'caring for one's self, performing manual tasks, walking, seeing, hearing, speaking, breathing, learning, and working' are." 2 The chief justice conceded that reproductive decisions are important, but he concluded that what is common to major life activities is not their importance but the fact that they "are repetitively performed and essential in the dayto-day existence of a normally functioning individual. They are thus quite different from the series of activities leading to the birth of a child." ${ }^{2}$

Moreover, the chief justice observed, even if he agreed that reproduction was a major life activity, he would still disagree that HIV infection "substantially limits" it, because "those so infected are still entirely able to engage in sexual intercourse, give birth to a child if they become pregnant, and perform the manual tasks necessary to rear a child to maturity." 
The fact that someone infected with HIV "may choose not to engage in these activities" does not mean that HIV infection constitutes a limit on one's life activities. ${ }^{2}$ The chief justice wrapped up his argument by noting that the Court's position, "taken to its logical extreme, would render every individual with a genetic marker for some debilitating disease 'disabled' here and now because of some possible future effects." 2 On the question of a "direct threat," the chief justice agreed that the case should be remanded for a full hearing but stated that the courts should be more sympathetic to the dentist's view of the risk given the severity of the risk. ${ }^{2}$

\section{HIV AND DISABILITY}

The question posed by Bragdon v. Abbott is what Congress intended when it passed the ADA. The Supreme Court's conclusion that Congress intended the ADA to apply to persons with HIV infection is consistent with virtually everything written on the subject. For example, the Court noted that before the ADA was passed, every court and every administrative agency that had considered the issue under the Rehabilitation Act had found that it provided protection against discrimination for persons with HIV infection. ${ }^{2}$ Congress, of course, knew of these interpretations before passing the ADA. The Court concluded that in passing the ADA, Congress "intended to give that position its active endorsement." ${ }^{2}$

The majority of the Court decided that reproduction is a major life activity under the ADA. Nonetheless, the opinion left many questions unresolved. The first involves the nature of reproduction itself. The Supreme Court assumes that reproduction will be accomplished by sexual intercourse, and it is this act that puts the sexual partner at risk. Of course, with the new techniques of assisted reproduction, sexual intercourse is not required for reproduction. Moreover, with the use of donor gametes and a "surrogate" mother, there is no risk of transmitting HIV to the child. The point is that what HIV infection really limits is the combination of sex and reproduction, not either one in isolation. HIVinfected persons can take precautions - much the way the dentist could have - and continue to have "safe sex." And using the new reproductive techniques, HIV-infected persons can reproduce without putting anyone else at risk of infection. The Supreme Court's decision, however, might mean that infertile persons who needed time off from work to undergo treatment for infertility could not be discriminated against for this reason. ${ }^{5,6}$ The Court did not discuss the question of whether the patient would be protected by the ADA if she were infertile (e.g., because of a hysterectomy) before she became infected with HIV, nor did it discuss the question of whether gay or lesbian patients would be protected, although the Court properly noted that others are likely to contend that "HIV infection imposes substantial limitations on other major life activities." 2

\section{REPRODUCTION AND RISK}

More interesting is the Court's view of risk. HIVinfected women can, of course, have children, and many do. There is, however, a risk, often estimated at about 25 percent, that the mother will transmit HIV to her child. The risk can be reduced to about 8 percent with the use of a zidovudine treatment regimen. ${ }^{7}$ The Court concluded, in an unartful sentence, that an 8 percent risk of transmitting "a dread and fatal disease to one's child" is a "substantial limitation on reproduction." 2 Of course, if the risk of HIV transmission from mother to child were reduced to zero or nearly zero because of improved prevention methods, HIV would then no longer substantially limit reproduction. Elimination of the risk associated with reproduction would not necessarily disqualify HIV as a disability, but another major life activity, such as education or employment, would have to be restricted for HIV infection to be covered by the ADA. On the other hand, as the chief justice properly recognized, if the reasoning that an 8 percent risk substantially limits reproduction were "taken to its logical extreme," everyone who was the carrier of a debilitating genetic disease would be considered disabled. ${ }^{2}$ Also, since the Court believes that persons infected with HIV are disabled from the moment of infection (even if they do not know they are infected), everyone who carries such genes could be considered disabled from birth.

The question of genetic disability was not examined in this decision, but a few points are worth making. First, in the case of most persons who carry genes for "dread and fatal" diseases, the genes are recessive, and a carrier of a recessive gene must reproduce with another carrier of the same gene to incur the risk of having children with the disease itself (usually a 25 percent risk). In such a case, is it only the couple as a couple that is disabled (in which case the ADA does not offer protection), or is each member of the couple disabled? Moreover, prenatal tests are available for some diseases (e.g., Tay-Sachs disease), and if the results are positive, the pregnancy can be aborted. Since prenatal testing eliminates the risk of transmitting the disease to a child, is the condition still one that "substantially limits" reproduction? And are persons who are carriers of genes that predispose them to "dread" diseases (such as breast cancer) disabled, even though they have no disease themselves? $\$ 8,9$

\section{HEALTH CARE AND RISK}

Once the issue of disability has been resolved, the only remaining question is whether the health care provider can establish that the disabled person poses "a direct threat" to the provider. The issue of risk 
has been at the heart of the HIV epidemic for more than a decade: What is the risk of transmission of HIV from health care provider to patient and from patient to health care provider? This question became a national obsession with the death of Kimberly Bergalis in 1991 at the age of 23 years. Bergalis was the first person known to have been infected with HIV by a health care provider (her dentist, David Acer). Many individuals and organizations, including the U.S. Senate, the CDC, and the American Medical Association, overreacted to her death by recommending that all infected health care providers refrain from performing invasive procedures. ${ }^{10} \mathrm{In}$ stead of focusing on whether there was a "significant risk" of transmission from health care practitioner to patient, discussions of the Bergalis case focused on whether there was any risk. The fact that Bragdon v. Abbott involves a dentist's fear of his patient rather than a patient's fear of her dentist does not change the risk analysis of disability. The question is whether disabled persons can be excluded from important human activities because others would prefer not to deal with them out of prejudice or irrational fear.

Bragdon v. Abbott was remanded to the Circuit Court of Appeals to reconsider the issue of the risk of HIV transmission to the dentist. The majority of the justices on the Supreme Court seem to believe that the dentist will be unable to demonstrate a "significant risk" of harm, whereas the minority seem to believe that the dentist will prevail. The majority opinion is almost certainly correct. The standard for permissible discrimination against a disabled person was set forth by the Court in 1987 in School Board of Nassau County v. Arline, a case in which the Supreme Court prohibited a school board from firing a teacher who had a recurrence of tuberculosis contracted 20 years earlier. ${ }^{11}$ The Court found that she was a "handicapped individual" under the Rehabilitation Act of 1973 and thus was protected against discrimination unless she posed "a significant risk of communicating an infectious disease to others in the workplace . . . if a reasonable accommodation will not eliminate that risk." "ll The Court specified that an "individualized inquiry" must be made in each case.

The American Medical Association offered standards for such an inquiry that were adopted by the Court: the determination of "significant risk" should be based "on reasonable medical judgments given the state of medical knowledge" about how the disease is transmitted, the duration of the risk, the severity of the potential harm if the disease is transmitted, and the probability of transmission. ${ }^{11}$ This approach was adopted in the ADA, which permits a defense against a charge of discrimination if the disabled person poses "a direct threat," defined as "a significant risk to the health or safety of others that cannot be eliminated by a modification of policies, practices, or procedures or by the provision of aux- iliary aids or services." An assessment of the risk must be based on "medical or other objective evidence." 2 The party that wishes to exclude the disabled person has the burden of proving that the person poses a direct threat.

Under these standards, the dentist will not be able to demonstrate that filling the tooth of an HIVinfected patient poses a "significant risk" to himself or his staff. The chief justice may have believed that the dentist could prove his case because he conflated two equally important requirements: the demonstration of a "significant risk" and the demonstration of "substantial harm." There is no question that HIV infection is a substantial harm; the probability of this harm, however, is an independent factor in determining whether a risk is significant. The chief justice, relying entirely on a 1994 CDC report of seven "possible" cases of transmission of HIV from patients to dental workers, concluded, "Given the 'severity of the risk' involved here, i.e., near certain death, and the fact that no public health authority had outlined a protocol for eliminating this risk in the context of routine dental treatment, it seems likely that petitioner can establish that it was objectively reasonable for him to conclude that treating respondent in his office posed 'a direct threat' to his safety." 2

The chief justice adopted the historically seductive argument that any possible risk of death should be sufficient to justify excluding people with disabilities from activities, regardless of how low the probability of harm is. This is the same argument that was used in the past to prevent wheelchair users from flying on commercial airplanes and hearing-aid users from driving buses. ${ }^{12,13}$ The argument has also been accepted by lower-court judges to exclude HIV-infected physicians from performing surgery ${ }^{14}$ and HIVinfected nurses from practicing nursing. ${ }^{15}$ The issue, however, is not only the possibility of death but also the likelihood of the risk of death. In the Court's words, "few, if any, activities in life are risk free, and the ADA does not ask whether a risk exists, but whether it is significant." Rehnquist's argument, taken to its logical extreme, would mean that no patients with potentially fatal infectious diseases, including hepatitis $\mathrm{B}$, are protected from discrimination by the ADA, since the health care provider's risk of contracting such a disease from a patient will always be greater than zero. This result would undermine the very purpose of the act. In this case, the risk of HIV transmission was extremely low, certainly so low that it cannot be used as a justification for discrimination against HIV-infected patients. ${ }^{10}$ If there were a significant risk of infection, it is unlikely that either the American Dental Association or Bragdon would rely on questionnaires to determine the HIV status of patients; mandatory testing would be required. By making discrimination unlawful, the ADA actually encourages people at risk to be tested for HIV. 
The ADA is a historic civil-rights law that properly protects all disabled Americans from many forms of discrimination that result from fear and prejudice. As former President George Bush put it when he signed the act, referring to the estimated 43 million disabled Americans, "Every man, woman, and child with a disability can now pass through a once-closed door to a bright new era of equality, independence, and freedom." The application of the law to HIV infection, in the context of continuing stigmatization and discrimination in the health care setting, has now been properly affirmed by the Supreme Court. This decision comports with the ethical principles of the medical and dental professions and with the use of universal precautions.

\section{REFERENCES}

1. Americans with Disabilities Act of 1990,104 Stat. 327, 42 U.S.C. sec. 12101 et seq.
2. Bragdon v. Abbott, 118 S. Ct. 2196 (1998)

3. Abbott v. Bragdon, 912 F. Supp. 580 (D.Me. 1995)

4. Bragdon v. Abbott, 107 F.3d 94 (lst Cir. 1997).

5. Tomkowicz SM. The disabling effects of infertility: fertile grounds for accommodating infertile couples under the Americans with Disabilities Act. Syracuse Law Rev 1996;46:1051-92.

6. Fein E. AIDS virus case opens door for infertile. New York Times. July 5, 1998:E6.

7. Connor EM, Sperling RS, Gelber R, et al. Reduction of maternalinfant transmission of human immunodeficiency virus type 1 with zidovudine treatment. N Engl J Med 1994;331:1173-80.

8. Gin BR. Genetic discrimination: Huntington's disease and the Americans with Disabilities Act. Columbia Law Rev 1997;87:1406-33.

9. Annas GJ. When should preventive treatment be paid for by health insurance? N Engl J Med 1994;331:1027-30.

10. Glantz LH, Mariner WK, Annas GJ. Risky business: setting public health policy for HIV-infected health care professionals. Milbank Q 1992 70:43-79.

11. School Board of Nassau County v. Arline, 480 U.S. 273 (1987). 12. Holmes $S$. For 2 nd time recently, an airline bars a Bush aide in a wheelchair. New York Times. October 6, 1991:24.

13. Strathie v. Department of Transportation, 716 F.2d 227 (3d Cir. 1983). 14. Estate of Behringer v. Medical Center at Princeton, 249 N.J. Super. 597, 592 A.2d 1251 (1991).

15. Leckelt v. Board of Commissioners of Hospital District 1, 909 F.2d 820 (5th Cir. 1990).

FULL TEXT OF ALL JOURNAL ARTICLES ON THE WORLD WIDE WEB

Access to the complete text of the Journal on the Internet is free to all subscribers. To use this Web site, subscribers should go to the Journal's home page (www.nejm.org) and register by entering their names and subscriber numbers as they appear on their mailing labels. After this one-time registration, subscribers can use their passwords to $\log$ on for electronic access to the entire Journal from any computer that is connected to the Internet. Features include a library of all issues since January 1993, a full-text search capacity, a personal archive for saving articles and search results of interest, and free software for downloading articles so they can be printed in a format that is virtually identical to that of the typeset pages. 